\title{
Persepsi Kepercayaan, Kegunaan, Kemudahan Penggunaan, Keamanan dan Minat Ulang Menggunakan Mobile Banking Jenius
}

\author{
Ni Wayan Gita 1 \\ Fakultas Ekonomi dan Bisnis \\ Universitas Udayana, Indonesia
}

\author{
Gede Juliarsa ${ }^{2}$ \\ Fakultas Ekonomi dan Bisnis \\ Universitas Udayana, Indonesia
}

Surel : niwayangita99@gmail.com

\section{ABSTRAK}

Penelitian ini bertujuan untuk mengetahui pengaruh persepsi kepercayaan, kegunaan, kemudahan penggunaan, dan keamanan pada minat ulang menggunakan mobile banking Jenius. Penelitian ini memakai teknik non-probability sampling yaitu purposive sampling. Total sampel yang dipakai yakni 145 responden yang merupakan pengguna mobile banking Jenius dan bersedia menjadi responden. Teknik analisis yang digunakan adalah analisis regresi linear berganda dengan bantuan software IBM SPSS Statistics 25. Berdasarkan analisis, ditemukan bahwa persepsi kepercayaan berpengaruh positif pada minat ulang menggunakan mobile banking Jenius. Persepsi kegunaan mempunyai pengaruh positif pada minat ulang menggunakan mobile banking Jenius. Persepsi kemudahan penggunaan tidak mempunyai pengaruh pada minat ulang menggunakan mobile banking Jenius. Persepsi keamanan mempunyai pengaruh positif pada minat ulang menggunakan mobile banking Jenius.

Kata Kunci: Kepercayaan; Kegunaan; Kemudahan Penggunaan; Keamanan; Minat Ulang.

\section{Perceived Trust, Usability, Ease of Use, Security and Reinterest in Using Jenius Mobile Banking}

\begin{abstract}
This study aims to determine the effect of perceived trust, usability, ease of use, and security on re-interest in using Jenius mobile banking. This study uses a non-probability sampling method with a purposive sampling technique. The number of samples used in this study were 145 respondents with criteria as Jenius mobile banking users and willing to become respondents. The analysis technique used is multiple linear regression analysis with the help of IBM SPSS Statistics 25 software. Based on the analysis, it is found that the perception of trust has a positive effect on re-interest in using Jenius mobile banking. Usability perception has a positive effect on re-interest in using Jenius mobile banking. Perceived ease of use has no effect on re-interest in using Jenius mobile banking. Perception of security has a positive effect on re-interest in using the Jenius mobile banking.
\end{abstract}

Keywords: Trust; Usefulness; Ease of Use; Security; Re-interest.

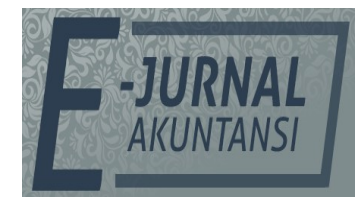

e-ISSN 2302-8556

Vol. 31 No. 8

Denpasar, Agustus 2021 Hal. 2086-2099

10.24843/EJA.2021.v31.i08.p16

PENGUTIPAN:

Gita, N.W., \& Juliarsa, G. (2021). Persepsi Kepercayaan,

Kegunaan, Kemudahan

Penggunaan, Keamanan dan Minat Ulang Menggunakan Mobile Banking Jenius. EJurnal Akuntansi, 31(8), 2086-

2099

RIWAYAT ARTIKEL: Artikel Masuk: 27 April 2021 Artikel Diterima: 29 Juli 2021

Artikel dapat diakses : https://ojs.unud.ac.id/index.php/Akuntansi/index 


\section{PENDAHULUAN}

Teknologi informasi berkembang dengan sangat pesat seiring perkembangan zaman. Pesatnya perkembangan teknologi mengharuskan masyarakat melakukan aktivitas yang cepat, efektif, dan efisien khususnya saat melakukan kegiatan transaksi. Satu dari sekian sektor yang wajib membuka diri dengan kemajuan teknologi ialah perbankan. Umumnya transaksi perbankan dilakukan secara manual, nasabah mendatangi bank, mengisi formulir, dan menunggu antrian. Aktivitas tersebut sangat tidak efisien baik dari segi waktu dan biaya yang terbuang cukup banyak. Oleh karena itu, dalam rangka meningkatkan pelayanannya, pihak bank memberikan solusi yaitu menggunakan mobile banking.

Mobile banking adalah sebuah fasilitas atau layanan perbankan yang menggunakan alat komunikasi bergerak seperti smartphone yang terhubung dengan jaringan internet. Mobile banking memberi kemudahan bagi nasabah untuk tidak harus datang ke bank atau ATM guna melakukan transaksi berupa transfer dana, pelunasan tagihan, pembelian pulsa dan pengecekan saldo rekening Mubiyantoro \& Syaefullah (2013). Kelebihan dari penyediaan mobile banking bagi sebuah bank ialah meminimalisir beban mencetak formulir, brosur, katalog, serta beralih ke data eletronik.

Selama beberapa tahun terakhir ini, pihak bank terus melakukan inovasi dan pengembangan pada layanan mobile banking yang dimiliki, seperti penambahan fitur dan perbaharuan interface pada aplikasi. Salah satu bank yang memiliki mobile banking adalah bank BTPN (Bank Tabungan Pensiunan Nasional) yang bernama Jenius. Aplikasi mobile banking Jenius resmi dirilis pada bulan Agustus tahun 2016 dan telah beroperasi di wilayah Jabodetabek dan Kota Bandung. Mobile banking Jenius berhasil menarik perhatian masyarakat karena berhasil membuat gebrakan pada fitur dan layanannya. Ini dibuktikan dengan pengguna yang bertambah banyak dan signifikan pada setiap tahunnya. Berikut disajikan jumlah pengguna Jenius dari tahun 2016 sampai 2020.

Tabel 1. Jumlah Pengguna Jenius dari Tahun 2016 sampai 2020

\begin{tabular}{|c|c|c|c|}
\hline No & Tahun & Bulan & Jumlah \\
\hline \multirow{2}{*}{1} & \multirow{2}{*}{2017} & Juni & 301.000 \\
\hline & & Desember & 350.000 \\
\hline \multirow{2}{*}{2} & \multirow{2}{*}{2018} & Juni & 704.000 \\
\hline & & Desember & 1.200 .000 \\
\hline \multirow{2}{*}{3} & \multirow{2}{*}{2019} & Juni & 1.600 .000 \\
\hline & & Desember & 2.400 .000 \\
\hline \multirow{2}{*}{4} & \multirow{2}{*}{2020} & Juni & 2.700 .000 \\
\hline & & Desember & 3.100 .000 \\
\hline
\end{tabular}

Sumber: Data Penelitian, 2020

Berdasarkan Tabel 1, pengguna Jenius terus mengalami kenaikan yang signifikan dari tahun ke tahun. Pertumbuhan pengguna ini menunjukkan bahwa Jenius telah berhasil dalam mengembangkan teknologinya. Terlepas dari banyaknya pengguna Jenius, terdapat pula masalah keamanan pada mobile banking ini. Peristiwa pembobolan rekening dialami oleh dua nasabah Jenius pada Juni 2020. Menurut Tantrides dan Konjugasi dalam utas di Twitter, akun Jeniusnya telah dibobol dan mengaku telah kehilangan saldo Jenius tanpa pernah melakukan transaksi apapun (Tenri Gobel, 2020). Kejadian ini membuat nasabah 
mempertimbangkan minatnya untuk menggunakan ulang mobile banking Jenius karena masalah keamanan.

Fenomena terkait cara klien mampu mengadaptasi dengan maksimal fasilitas mobile banking, dapat dijelaskan melalui model TAM (Technology Accepttance Model). Teori ini memberikan penjelasan sederhana namun kuat dalam hal akseptasi teknologi serta aktivitas pemakainya. TAM diperkenalkan oleh Davis (1989) pada kerangka berpikir terkait intensi memanfaatkan teknologi informasi. TAM banyak dimanfaatkan guna meramalkan tingkat penerimaan pengguna yang berdasar pada keyakinan tentang kegunaan teknologi informasi melalui peninjauan tingkat kemudahan penggunaan teknologi informasi.

Mobile banking menawarkan begitu banyak kemudahan dan manfaat, namun pada kenyataanya fasilitas ini belum sepenuhnya dapat menarik minat konsumen (nasabah) untuk menggunakannya. Menurut Jogiyanto (2007) minat perilaku adalah suatu keinginan seseorang untuk melakukan suatu perilaku tertentu. Minat atau intensi dalam memakai sebuah teknologi terbaru seperti mobile banking disebabkan oleh beberapa hal seperti tanggapan nasabah tersebut tentang mobile banking. Persepsi manfaat adalah hal yang sangat diperhatikan oleh nasabah dalam menggunakan mobile banking. Persepsi kegunaan yakni kepercayaan seseorang bahwa pemakaian sistem teknologi informasi mampu menambah utilitas untuk melakukan suatu kegiatan serta memperbaiki performanya (Davis, 2009).

Tidak hanya persepsi manfaat, kemudahan dalam menggunakannya menjadi hal yang krusial pula sebagai pertimbangan nasabah untuk memakai mobile banking. (Davis, 1989) mengemukakan, persepsi kemudahan penggunaan teknologi ialah ketika individu meyakini pengaplikasian teknologi tersebut itu tidak memerlukan usaha yang keras.

Persepsi kepercayaan juga menjadi salah satu hal yang perlu diperhatikan oleh nasabah dalam menggunakan mobile banking. Menurut Talatu et al., (2014) kepercayaan mampu mendorong tingkah laku pemakai mobile banking. Kepercayaan ialah keadaan psikis yang bergantung pada keadaan serta konteks social seseorang. Saat memutuskan sesuatu, seseorang cenderung mengambil keputusan sesuai opsi yang diberikan oleh orang-orang yang dipercaya.

Hal lainnya yang memengaruhi intensi pelanggan menggunakan teknologi adalah tingkat keamanan (security). Menurut Nasri \& Zarai (2014) keamanan merupakan perlindungan atas ancaman keamanan serta kontrol atas informasi pribadi pelanggan dalam bertransaksi secara daring. Apabila tingkat keamanan tinggi dan dijamin seluruh informasi pribadi pengguna aman, maka pengguna juga akan merasa aman dan tertarik mengadopsi teknologi tersebut, dan sebaliknya.

Penelitian ini adalah pengembangan dari penelitian Chuang \& Kao (2016) yang berjudul "The Adoption of Fintech Service: TAM perspective". Penelitian tersebut memiliki tujuan mencari korelasi dalam hal memanfaatkan teknologi finansial dengan menggunakan TAM. Hasil penelitian menunjukkan bahwa kepercayaan, persepsi kegunaan, persepsi kemudahan penggunaan berpengaruh positif dan signifikan pada intensi berperilaku dalam menggunakan layanan teknologi finansial. Peneliti menambahkan satu variabel, yaitu variabel keamanan berdasarkan fenomena yang sudah dijelaskan sebelumnya. Pada penelitian ini, 
peneliti menggunakan mobile banking Jenius sebagai objek karena peneliti sendiri menggunakan mobile banking Jenius.

Kepercayaan merupakan sebuah evaluasi korelasi dengan pihak lain yang menjalankan transaksi tertentu seperti keinginan dari lingkungan sekitar. Penelitian terdahulu oleh Chuang \& Kao (2016), dihasilkan kesimpulan kepercayaan pada suatu layanan mempunyai pengaruh yang positif dan signifikan pada sikap terhadap niat berperilaku memanfaatkan layanan teknologi finansial. Sesuai teori serta penelitian sebelumnya dapat dirumuskan hipotesis pertama sebagai berikut.

$\mathrm{H}_{1}$ : Kepercayaan mempunyai pengaruh positif pada minat ulang untukmenggunakan aplikasi mobile banking Jenius.

Persepsi kegunaan adalah keadaan dimana individu meyakini penggunaan sebuah sistem mampu mengefisienkan suatu kinerja (Fred D. Davis, 1989). Apabila seseorang berkeyakinan bahwa sistem bermanfaat maka ia akan mengadopsinya dan sebaliknya. Dalam penelitiannya, Hapsara \& Noer (2015) mendapatkan bahwa kegunaan, kemudahan, kepercayaan serta risiko atas penggunaan mobile banking mempunyai pengaruh pada intensi pelanggan untuk memakai mobile banking. Sesuai teori serta penelitian sebelumnya dapat dirumuskan hipotesis kedua sebagai berikut.

$\mathrm{H}_{2}$ : Persepsi kegunaan mempunyai pengaruh positif pada minat ulang untuk menggunakan aplikasi mobile banking Jenius.

Fred D. Davis (1989) memberikan makna persepsi kemudahan penggunaan teknologi adalah keadaan saat individu berkeyakinan, dalam memakai teknologi tak harus mengeluarkan banyak tenaga. Penelitian terdahulu oleh Chuang \& Kao (2016) menjelaskan bahwa persepsi kemudahan penggunaan mempunyai pengaruh positif dan signifikan pada sikap terhadap niat berperilaku dalam hal melakukan adopsi layanan teknologi finansial. Sesuai teori serta penelitian sebelumnya dapat dirumsukan hipotesis ketiga sebagai berikut.

$\mathrm{H}_{3}$ : Persepsi kemudahan penggunaan mempunyai pengaruh positif pada minat ulang untuk menggunakan aplikasi mobile banking Jenius.

Keamanan didefinisikan sebagai suatu langkah pencegahan agar suatu informasi tidak bocor ke pihak yang tidak diingkan. Saat ini keamanan menjadi penting, terutama yang berhubungan dengan penggunaan sistem atau teknologi. Penelitian yang telah dilakukan Utami \& Kusumawati (2017) menghasilkan kesimpulan keamanan mempunyai pengaruh positif pada intensi penggunaan layanan e-money. Penelitian oleh Ariani, (2017) menjelaskan, persepsi keamanan mempunyai pengaruh yang signifikan pada intensi penggunaan line pay. Atas dasar penelitian sebelumnya, dapat dirumuskan hipotesis keempat sebagai berikut.

$\mathrm{H}_{4}$ : Persepsi keamanan mempunyai pengaruh positif pada minat ulang untuk menggunakan aplikasi mobile banking Jenius.

Berikut disajikan model penelitian yang menunjukkan pengaruh variabel bebas terhadap variabel terikat. $\mathrm{H}$ adalah hipotesis yang menjelaskan persepsi kepercayaan, kegunaan, kemudahan penggunaan, serta keamanan pada minat ulang menggunakan mobile banking Jenius. 


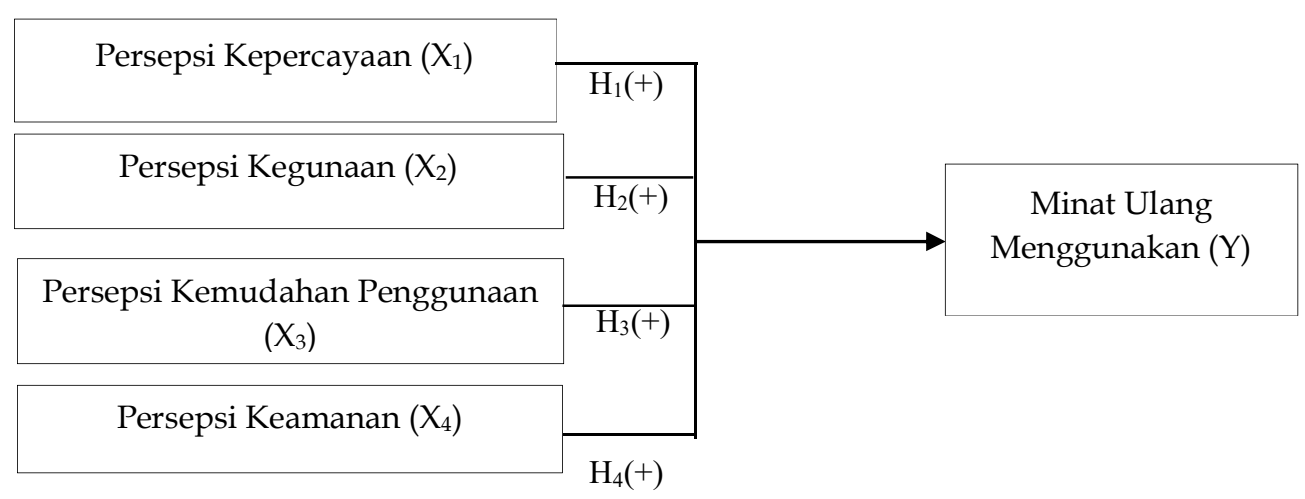

Gambar 1. Model Penelitian

Sumber: Data Penelitian,2021

\section{METODE PENELITIAN}

Penelitian ini dilakukan di Denpasar, Bali. Obyek dalam penelitian ini adalah persepsi kepercayaan, persepsi kegunaan, persepsi kemudahan penggunaan pada minat ulang menggunakan Jenius. Adapun variabel bebas pada penelitian ini adalah kepercayaan $\left(X_{1}\right)$, persepsi kegunaan $\left(X_{2}\right)$, persepsi kemudahan penggunaan $\left(X_{3}\right)$, dan keamanan $\left(X_{4}\right)$. Variabel terikat yang dipakai oleh peneliti adalah minat ulang menggunakan $(\mathrm{Y})$.

Populasi yang digunakan yakni masyarakat Indonesia yang pernah memakai aplikasi mobile banking Jenius. Non-probability sampling digunakan pada penelitian ini bertujuan agar setiap unsur atau anggota populasi tidak mempunyai peluang yang sama untuk dipilih menjadi sampel (Sugiyono, 2013). Penentuan subjek untuk dijadikan sampel atau responden dilakukan secara purposive sampling dengan kriteria: pengguna aplikasi mobile banking Jenius, bersedia menjadi responden. Berdasarkan Widiyono (2013), populasi penelitian ini berukuran cukup besar dan tidak dapat dideteksi jumlahnya, sehingga untuk mencari sampel digunakan rumus Rao Purba (Wiratna, 2015) sebagai berikut.

$$
\begin{aligned}
& n=\frac{Z^{2}}{4(M o e)^{2}} \ldots \ldots \ldots \ldots \ldots \ldots \ldots \\
& n=\frac{(1,96)^{2}}{4(0,05)^{2}}=384,16 \approx 385
\end{aligned}
$$

Keterangan :

$\mathrm{n}=$ Jumlah Sampel

$\mathrm{Z}=1,96$ (derajat keyakinan ditentukan 95 persen)

Moe $=$ Margin of error sebesar 5 persen atau 0,05

Berdasarkan perhitungan tersebut, sampel penelitian ini berjumlah 385 orang pengguna aplikasi mobile banking Jenius. Dalam periode penyebaran kuesioner selama sebulan, sebanyak 400 kuesioner telah disebar berdasarkan purposive sampling kepada pengguna Jenius. Namun, kuesioner yang diterima kembali atau diisi oleh responden hanya sebanyak 145. Dengan demikian, pengolahan data menggunakan 145 sampel. 
Teknik pengumpulan data yang dipakai ialah angket. Angket atau kuesioner merupakan teknik pengumpulan data dengan cara melemparkan pertanyaan ataupun pernyataan tertulis pada responden untuk selanjutnya dijawab sesuai opsi yang disediakan (Sugiyono, 2013). Pengolahan data memanfaatkan software SPSS. Software ini berguna untuk kegiatan analisis statistik yang meliputi : statistik deskriptif, uji instrumen, uji asumsi klasik, serta uji ketepatan model. Untuk menguji hipotesis satu, hipotesis dua dan seterusnya menggunakan uji regresi berganda yaitu sebagai berikut.

$Y=\alpha+\beta_{1} X_{1}+\beta_{2} X_{2}+\beta_{3} X_{3}+\beta_{4} X_{4}+\varepsilon$

Keterangan:

$\mathrm{Y}=$ Minat Ulang Penggunaan

$\mathrm{a} \quad=$ Konstanta

$\beta_{1}-\beta_{4}=$ Koefisien regresi dari setiap variabel independen

$\mathrm{X}_{1} \quad=$ Persepsi Kepercayaan

$\mathrm{X}_{2} \quad=$ Persepsi Kegunaan

$\mathrm{X}_{3} \quad=$ Persepsi Kemudahan Penggunaan

$\mathrm{X}_{4} \quad=$ Persepsi Keamanan

$\varepsilon \quad=$ Variabel pengganggu

\section{HASIL DAN PEMBAHASAN}

Responden dalam penelitian ini adalah masyarakat Indonesia yang pernah menggunakan mobile banking Jenius. Dalam penelitian ini, peneliti tidak dapat mengetahui secara pasti besarnya populasi yang akan diteliti, disebabkan tidak terdapatnya data yang akurat mengenai informasi jumlah pengguna mobile banking Jenius. Oleh karena itu, penentuan jumlah sampel dalam penelitian ini menggunakan metode non-probability sampling dengan teknik purposive sampling. Data tentang karakteristik responden berdasarkan jenis kelamin, usia, dan pekerjaan disajikan pada Tabel 1, berikut.

Tabel 2. Karakteristik Responden

\begin{tabular}{lllll}
\hline No & Variabel & Klasifikasi & Frekuensi & Persentase(persen) \\
\hline 1 & Jenis Kelamin & Laki-laki & 67 & 46,2 \\
& & Perempuan & 78 & 53,8 \\
& & & 145 & 100 \\
& Jumlah & $17-25$ tahun & 101 & 69,7 \\
& Usia & 35 & 24,1 \\
& & $96-35$ tahun & 6,2 \\
& & $46-55$ tahun & $\sim$ & $\sim$ \\
& Jumlah & 56 - 65 tahun & $\sim$ & 100 \\
& Pekerjaan & Pelajar/Mahasiswa & 63 & 43,4 \\
& & Pegawai Negeri & 13 & 9 \\
& & Pegawai Swasta & 43 & 29,7 \\
& & Wiraswasta & 9 & 6,2 \\
& & Ibu Rumah Tangga & 3 & 2,1 \\
& & Profesional & 7 & 4,8 \\
& & Lainnya & 7 & 4,8 \\
& & 145 & 100 \\
\hline
\end{tabular}

Sumber: Data Penelitian, 2021 
Dari Tabel 2, dapat diketahui bahwa responden dengan jenis kelamin lakilaki berjumlah 67 orang (46,2 persen) dan jenis kelamin perempuan berjumlah 78 orang (53,8 persen). Hasil ini menunjukkan bahwa mayoritas pengguna Jenius adalah berjenis kelamin perempuan. Responden dengan kelompok usia 17-25 tahun sebanyak 101 orang (69,7 persen), kelompok usia 26-35 tahun sebanyak 35 orang (24,1 persen), kelompok usia 36-45 tahun sebanyak 9 (6,2 persen), tidak terdapat responden yang berada pada kelompok usia 46-55 tahun dan 56-65 tahun. Hasil ini menunjukkan bahwa mayoritas responden adalah berada pada rentang usia 17-25 tahun. Responden yang berstatus pelajar/mahasiswa sebanyak 63 orang ( 43,4 persen), pegawai negeri berjumlah 13 orang ( 9 persen), pegawai swasta berjumlah 43 orang (29,7 persen), wiraswasta sebanyak 9 orang $(6,2$ persen), ibu rumah tangga sebanyak 3 orang (2,1 persen), professional sebanyak 7 orang ( 4,8 persen), dan pekerjaan lainnya (pengangguran, freelancer) sebanyak 7 orang ( 4,8 persen).

Analisis statistik deskriptif jawaban responden ini dilakukan terhadap 145 responden yang bertujuan untuk mengetahui tanggapan responden terhadap indikator-indikator yang ada pada kuesioner. Hal ini dilakukan dengan cara mengumpulkan jawaban responden berdasarkan skala dan indikator kemudian diolah secara statistik untuk mengetahui rata-rata jawaban responden, distribusi data, nilai maksimum dan minimum.

Berdasarkan hasil uji statistik deskriptif pada Tabel 3, dapat dilihat bahwa total sampel berjumlah 145 , nilai rata-rata seluruh variabel independen memiliki nilai yang tinggi, yaitu diatas 20 dari skor maksimum 30. Nilai rata-rata tertinggi berada pada persepsi kemudahan penggunaan yaitu 25,56, nilai ini mengimplikasikan bahwa responden menganggap bahwa mobile banking Jenius mudah untuk digunakan, Nilai rata-rata terendah adalah keamanan yaitu 22,57, nilai ini mengimplikasikan bahwa keamanan pada mobile banking Jenius kurang. Pada variabel dependen yaitu minat ulang, rata-ratanya sangat kecil yaitu 19,19.

Tabel 3. Hasil Uji Statistik Deskriptif

\begin{tabular}{lllllll}
\hline & & & & & & Std. \\
Variabel & $\mathrm{N}$ & Minimum & Maximum & Sum & Mean & Deviation \\
\hline Kepercayaan (X1) & 145 & 8 & 30 & 3410 & 23,52 & 4,784 \\
Kegunaan (X2) & 145 & 11 & 30 & 3640 & 25,10 & 4,175 \\
Kemudahan & 145 & 12 & 30 & 3706 & 25,56 & 3,889 \\
Penggunaan (X3) & & & & & & \\
Keamanan (X4) & 145 & 6 & 30 & 3273 & 22,57 & 6,289 \\
Minat Ulang Y & 145 & 5 & 25 & 2783 & 19,19 & 5,121 \\
Valid N (listwise) & 145 & & & & & \\
\hline
\end{tabular}

Sumber: Data Penelitian, 2021

Berdasarkan hasil uji validitas, diketahui bahwa $r$ hitung pada setiap indikator pada semua variabel persepsi kepercayaan $\left(X_{1}\right)$, persepsi kegunaan $\left(X_{2}\right)$, persepsi kemudahan penggunaan $\left(X_{3}\right)$, dan keamanan $\left(X_{4}\right)$ bernilai positif dan lebih besar dari $r$ tabel 0,162 $\left(r_{\text {hitung }}>r_{\text {tabel }}\right)$. Dilihat dari nilai sig. setiap indikator pada semua variabel persepsi kepercayaan $\left(X_{1}\right)$, persepsi kegunaan $\left(X_{2}\right)$, persepsi kemudahan penggunaan $\left(X_{3}\right)$, serta keamanan $\left(X_{4}\right)$, semua indikatornya memiliki nilai sig. $<a(0,05)$. Dapat disimpulkan bahwa semua indikator pada variabel pada penelitian ini adalah valid. 
GITA, N.W., \& JULIARSA, G.

Tabel 4. Hasil Uji Validitas

\begin{tabular}{|c|c|c|c|c|c|c|}
\hline No & Variabel & Item & $\begin{array}{l}\text { Nilai } r \\
\text { hitung }\end{array}$ & $\begin{array}{c}\text { Nilai r } \\
\text { tabel }\end{array}$ & Sig. & Keterangan \\
\hline \multirow{6}{*}{1} & \multirow{6}{*}{$\begin{array}{c}\text { Persepsi } \\
\text { Kepercayaan }\end{array}$} & K1 & 0,760 & 0,162 & 0,000 & Valid \\
\hline & & $\mathrm{K} 2$ & 0,759 & 0,162 & 0,000 & Valid \\
\hline & & K3 & 0,846 & 0,162 & 0,000 & Valid \\
\hline & & K4 & 0,877 & 0,162 & 0,000 & Valid \\
\hline & & K5 & 0,831 & 0,162 & 0,000 & Valid \\
\hline & & K6 & 0,864 & 0,162 & 0,000 & Valid \\
\hline \multirow{6}{*}{2} & \multirow{6}{*}{$\begin{array}{c}\text { Persepsi } \\
\text { Kegunaan }\end{array}$} & Kg1 & 0,827 & 0,162 & 0,000 & Valid \\
\hline & & Kg2 & 0,846 & 0,162 & 0,000 & Valid \\
\hline & & Kg3 & 0,850 & 0,162 & 0,000 & Valid \\
\hline & & Kg4 & 0,843 & 0,162 & 0,000 & Valid \\
\hline & & Kg5 & 0,845 & 0,162 & 0,000 & Valid \\
\hline & & Kg6 & 0,746 & 0,162 & 0,000 & Valid \\
\hline \multirow{6}{*}{3} & \multirow{6}{*}{$\begin{array}{c}\text { Persepsi } \\
\text { Kemudahan } \\
\text { Penggunaan }\end{array}$} & Kp1 & 0,872 & 0,162 & 0,000 & Valid \\
\hline & & Kp2 & 0,818 & 0,162 & 0,000 & Valid \\
\hline & & Kp3 & 0,831 & 0,162 & 0,000 & Valid \\
\hline & & Kp4 & 0,907 & 0,162 & 0,000 & Valid \\
\hline & & Kp5 & 0,763 & 0,162 & 0,000 & Valid \\
\hline & & Kp6 & 0,758 & 0,162 & 0.000 & Valid \\
\hline \multirow{6}{*}{4} & \multirow{6}{*}{$\begin{array}{c}\text { Persepsi } \\
\text { Keamanan }\end{array}$} & Ke1 & 0,912 & 0,162 & 0,000 & Valid \\
\hline & & Ke2 & 0,938 & 0,162 & 0,000 & Valid \\
\hline & & Ke3 & 0,944 & 0,162 & 0,000 & Valid \\
\hline & & Ke4 & 0,948 & 0,162 & 0,000 & Valid \\
\hline & & Ke5 & 0,940 & 0,162 & 0,000 & Valid \\
\hline & & Ke6 & 0,913 & 0,162 & 0,000 & Valid \\
\hline \multirow{5}{*}{5} & \multirow{5}{*}{$\begin{array}{l}\text { Minat Ulang } \\
\text { Menggunakan }\end{array}$} & Mu1 & 0,930 & 0,162 & 0,000 & Valid \\
\hline & & $\mathrm{Mu} 2$ & 0,888 & 0,162 & 0,000 & Valid \\
\hline & & Mu3 & 0,857 & 0,162 & 0,000 & Valid \\
\hline & & Mu4 & 0,805 & 0,162 & 0,000 & Valid \\
\hline & & Mu5 & 0,924 & 0,162 & 0,000 & Valid \\
\hline
\end{tabular}

Sumber: Data Penelitian, 2021

Berdasarkan pada Tabel 5, diketahui bahwa nilai Alpha Cronbach pada setiap variabel penelitian memiliki nilai lebih besar dari 0,7, maka dapat disimpulkan bahwa semua variabel penelitian adalah reliabel.

Tabel 5. Hasil Uji Reliabilitas

\begin{tabular}{clcccc}
\hline No & \multicolumn{1}{c}{ Variabel } & $\begin{array}{c}\text { Total } \\
\text { item }\end{array}$ & $\begin{array}{c}\text { Cronbach } \\
\text { Alpha }\end{array}$ & $\begin{array}{c}\text { Nilai } \\
\text { Parameter }\end{array}$ & Keterangan \\
\hline 1 & Persepsi Kepercayaan & 6 & 0,905 & 0,7 & Reliabel \\
2 & $\begin{array}{l}\text { Persepsi Kegunaan } \\
\text { Persepsi Kemudahan }\end{array}$ & 6 & 0,907 & 0,7 & Reliabel \\
3 & Penggunaan & 6 & 0,905 & 0,7 & Reliabel \\
4 & $\begin{array}{l}\text { Persepsi Keamanan } \\
\text { Minat Ulang }\end{array}$ & 6 & 0,970 & 0,7 & Reliabel \\
5 & Menggunakan & 5 & 0,926 & 0,7 & Reliabel \\
\hline
\end{tabular}

Sumber: Data Penelitian, 2021 
Sesuai hasil uji normalitas pada Tabel 6, menggunakan metode Kolomogrov Smirnov diketahui nilai signifikansi 0,200 > 0,05, maka dapat disimpulkan bahwa nilai residual berdistribusi normal.

Tabel 6. Hasil Uji Normalitas

\begin{tabular}{lll}
\hline & & Unstandardized Residual \\
\hline $\mathrm{N}$ & & 145 \\
Normal Parameters & Mean & 0,0000000 \\
& Std. Deviation & 2,91364072 \\
Most Extreme Differences & Absolute & 0,067 \\
& Positive & 0,067 \\
& Negative & $-0,065$ \\
Test Statistic & & 0,067 \\
Asymp. Sig. (2-tailed) & .200 \\
\hline
\end{tabular}

Sumber: Data Penelitian, 2021

Dari hasil uji heterokedastisitas menggunakan Uji Glejser pada Tabel 7, hasil signifikansi dari masing-masing variabel bebas adalah lebih dari 0,05, ini menunjukkan bahwa tidak terjadi masalah heteroskedastisitas.

Tabel 7. Hasil Uji Heteroskedastisitas

\begin{tabular}{lll}
\hline Variabel & Sig. & Keterangan \\
\hline Kepercayaan (X1) & 0,214 & Tidak ada gejala Heteroskedastisitas \\
Kegunaan (X2) & 0,641 & Tidak ada gejala Heteroskedastisitas \\
Kemudahan Penggunaan (X3) & 0,529 & Tidak ada gejala Heteroskedastisitas \\
Keamanan (X4) & 0,214 & Tidak ada gejala Heteroskedastisitas \\
\hline
\end{tabular}

Sumber: Data Penelitian, 2021

Dari hasil perhitungan yang ada pada tabel hasil uji multikolinearitas, variabel bebas memperlihatkan nilai VIF dari setiap variabel $<10$ serta nilai tolerance dari setiap variabel $>0,10$, artinya data tersebut tidak mengandung gejala multikolinearitas.

Tabel 8. Hasil Uji Multikolinearitas

\begin{tabular}{|c|c|c|c|}
\hline \multirow{2}{*}{ Variabel } & \multicolumn{2}{|c|}{ Collinearity Statistics } & \multirow{2}{*}{ Keterangan } \\
\hline & Tolerance & VIF & \\
\hline Kepercayaan (X1) & 0,272 & 3,676 & Bebas Multikolinearitas \\
\hline Kegunaan (X2) & 0,420 & 2,381 & Bebas Multikolinearitas \\
\hline Kemudahan Penggunaan (X3) & 0,536 & 1,867 & Bebas Multikolinearitas \\
\hline Keamanan $(X 4)$ & 0,350 & 2,858 & Bebas Multikolinearitas \\
\hline
\end{tabular}

Sumber: Data Penelitian, 2021

Berdasarkan analisis data menggunakan SPSS 25, diperoleh hasil persamaan regresi sebagai berikut.

$$
Y=-3,504+0,451 X_{1}+0,196 X_{2}+0,064 X_{3}+0,242 X_{4}+\varepsilon
$$

Nilai konstanta adalah $-3,504$, artinya jika tidak terjadi perubahan variabel persepsi kepercayaan, kegunaan, kemudahan penggunaan, dan keamanan (nilai $\beta_{1-} \beta_{4}$ adalah 0) maka minat ulang menggunakan aplikasi mobile banking Jenius akan bernilai $-3,504$. Nilai koefisien regresi $\left(\beta_{1}\right)$ persepsi kepercayaan $\left(X_{1}\right)$ adalah 0,451 . Koefisien regresi bernilai positif menunjukkan bahwa jika persepsi kepercayaan meningkat satu satuan, maka minat ulang menggunakan aplikasi mobile banking Jenius akan meningkat sebesar 0,451 satuan dengan asumsi variabel bebas lainnya bernilai konstan. Nilai koefisien regresi $\left(\beta_{2}\right)$ persepsi kegunaan $\left(X_{2}\right)$ adalah 0,196. Koefisien regresi bernilai positif menunjukkan bahwa jika persepsi 
kegunaan mengalami peningkatan sebesar satu satuan, minat ulang menggunakan aplikasi mobile banking Jenius mengalami peningkatan pula sejumlah 0,196 satuan, diasumsikan variabel bebas lainnya bernilai konstan. Nilai koefisien regresi $\left(\beta_{3}\right)$ persepsi kemudahan penggunaan $\left(X_{3}\right)$ adalah 0,064 . Koefisien regresi bernilai positif menunjukkan bahwa jika persepsi kemudahan penggunaan meningkat satu satuan, minat ulang menggunakan aplikasi mobile banking Jenius akan mengalami peningkatan sejumlah 0,064 satuan dengan asumsi variabel bebas lainnya bernilai konstan. Nilai koefisien regresi $\left(\beta_{4}\right)$ persepsi keamanan $\left(X_{4}\right)$ adalah 0 ,242. Koefisien regresi bernilai positif menunjukkan bahwa jika persepsi keamanan meningkat satu satuan, minat ulang menggunakan aplikasi mobile banking Jenius mengalami peningkatan pula sejumlah 0,196 satuan, jika diasumsikan variabel bebas lainnya bernilai konstan.

Tabel 9. Hasil Uji Analisis Linear Berganda

\begin{tabular}{|c|c|c|c|c|c|c|}
\hline \multirow{2}{*}{\multicolumn{2}{|c|}{ Model }} & \multicolumn{2}{|c|}{ Unstandardized Coefficients } & \multirow{2}{*}{$\begin{array}{l}\text { Standardized } \\
\text { Coefficients } \\
\text { Beta } \\
\end{array}$} & \multirow[b]{2}{*}{$\mathrm{T}$} & \multirow[b]{2}{*}{ Sig. } \\
\hline & & $\mathrm{B}$ & Std. Error & & & \\
\hline 1 & (Constant) & $-3,504$ & 1,744 & & $-2,010$ & 0,046 \\
\hline & Kepercayaan $\left(\mathrm{X}_{1}\right)$ & 0,451 & 0,099 & 0,421 & 4,570 & 0,000 \\
\hline & $\operatorname{Kegunaan}\left(\mathrm{X}_{2}\right)$ & 0,196 & 0,091 & 0,160 & 2,156 & 0,033 \\
\hline & $\begin{array}{l}\text { Kemudahan } \\
\text { Penggunaan }\left(X_{3}\right)\end{array}$ & 0,067 & 0,087 & 0,051 & 0,770 & 0,443 \\
\hline & $\operatorname{Keamanan}\left(\mathrm{X}_{4}\right)$ & 0,242 & 0,066 & 0,297 & 3,657 & 0,000 \\
\hline
\end{tabular}

Sumber: Data Penelitian, 2021

Berdasarkan Tabel 10, dapat diketahui nilai $\mathrm{F}_{\text {hitung }}$ sebesar 73,127 dengan nilai $F_{\text {tabel }} 2,44$ sehingga nilai Fhitung $(73,127)>$ Ftabel $(2,44)$ serta nilai signifikan $0,000<0,05$. Artinya, variabel persepsi kepercayaan $\left(X_{1}\right)$, kegunaan $\left(X_{2}\right)$, kemudahan penggunaan $\left(X_{3}\right)$, dan keamanan $\left(X_{4}\right)$ secara simultan mempunyai pengaruh pada minat ulang menggunakan aplikasi mobile banking Jenius.

Tabel 10. Hasil Uji F

\begin{tabular}{lllllll}
\hline \multirow{2}{*}{ Model } & \multicolumn{2}{l}{ Sum of } & & & \\
& Squares & Df & Mean Square & F & Sig. \\
\hline $1 \quad$ Regression & 2554,134 & 4 & 638,533 & 73,127 & $0,000^{\mathrm{b}}$ \\
& Residual & 1222,460 & 140 & 8,732 & & \\
\multicolumn{1}{l}{ Total } & 3776,593 & 144 & & & \\
\hline
\end{tabular}

Sumber: Data Penelitian, 2021

Sesuai Tabel 11, terlihat bahwa nilai Adjusted $R$ Square yaitu 0,667. Hal tersebut menunjukkan bahwa kekuatan variabel independen untuk mempengaruhi variabel dependen yaitu sejumlah 66,7 persen. Sedangkan 33,3 persen dapat dipengaruhi oleh variabel lainnya yang tidak digunakan pada penelitian ini. Oleh karena itu, berdasarkan kriteria yang ada dapat dijelaskan variabel persepsi kepercayaan, kegunaan, kemudahan penggunaan dan keamanan berpengaruh yang cukup tinggi pada variabel minat ulang penggunaan karena menghasilkan koefisien determinan sebesar 66,7 persen.

Tabel 11. Hasil Uji Koefisien Determinasi $\left(\mathbf{R}^{2}\right)$

\begin{tabular}{lllll}
\hline Model & $\mathrm{R}$ & $\mathrm{R}$ Square & Adjusted $R$ Square & $\begin{array}{l}\text { Std. Error of the } \\
\text { Estimate }\end{array}$ \\
\hline 1 & $0,822^{\mathrm{a}}$ & 0,676 & 0,667 & 2,955 \\
\hline
\end{tabular}

Sumber: Data Penelitian, 2021 
Dilihat berdasarkan Tabel 12, signifikansi persepsi kepercayaan $\left(X_{1}\right) 0,000<$ 0,05 , dan nilai $t_{\text {hitung }}$ lebih besar dari $t_{\text {tabel }}(4,570>1,977)$, maka $\mathrm{H}_{0}$ ditolak dan $\mathrm{H}_{1}$ diterima. Berdasarkan hasil tersebut, terlihat persepsi kepercayaan mempunyai pengaruh positif pada minat ulang pengguna dalam memakai aplikasi mobile banking Jenius. Kepercayaan menjadi faktor yang sangat penting dalam melakukan transaksi online karena nasabah yakin bahwa pihak yang dipercaya dapat memenuhi komitmennya. Tidak hanya itu, kepercayaan akan mempengaruhi citra dari perusahaan tersebut. Menurut nasabah, Jenius memiliki sistem yang handal, reputasi yang baik, banyak fitur yang bermanfaat, hal ini dinilai nasabah sebagai bentuk komitmen Jenius dalam memberikan pelayanan yang terbaik untuk nasabah. Hal tersebut membuat nasabah Jenius memiliki kepercayaan pada Jenius. Berbeda dengan hasil penelitian yang dilakukan oleh Much (2018) yang menyatakan bahwa persepsi kepercayaan tidak berpengaruh pada minat menggunakan teknologi. Hasil penelitian ini konsisten dengan penelitian yang dilakukan Suh \& Han (2003), Chuang \& Kao (2016) dan Romadloniyah \& Prayitno (2018) yang menyatakan bahwa kepercayaan berpengaruh positif dan signifikan pada sikap terhadap niat berperilaku dalam menggunakan sistem teknologi.

Tabel 12. Hasil Uji t

\begin{tabular}{lcccl}
\hline Variabel Bebas & $\mathfrak{t}_{\text {tabel }}$ & $\mathrm{t}_{\text {hitung }}$ & Sig. & $\begin{array}{l}\text { Evaluasi } \\
\text { Hipotesis }\end{array}$ \\
\hline Kepercayaan $\left(\mathrm{X}_{1}\right)$ & 1,977 & 4,570 & 0,000 & Terbukti \\
Kegunaan $\left(\mathrm{X}_{2}\right)$ & 1,977 & 2,156 & 0,033 & Terbukti \\
Kemudahan Penggunaan $\left(\mathrm{X}_{3}\right)$ & 1,977 & 0,770 & 0,443 & Tidak Terbukti \\
Keamanan $\left(\mathrm{X}_{4}\right)$ & 1,977 & 3,657 & 0,000 & Terbukti \\
\hline
\end{tabular}

Sumber: Data Penelitian, 2021

Signifikansi persepsi kegunaan $\left(X_{2}\right) 0,033<0,05$, serta nilai $t_{\text {hitung }}>t_{\text {tabel }}(2,156$ $>1,977)$, maka $\mathrm{H}_{2}$ diterima ( $\mathrm{H}_{0}$ ditolak). Dapat diartikan bahwa variabel persepsi kegunaan memiliki pengaruh positif pada intensi ulang menggunakan aplikasi mobile banking. Semakin tinggi manfaat yang dimiliki sebuah teknologi, makin tinggi juga intensi penggunaan teknologi itu (termasuk teknologi mobile banking). Manfaat layanan Jenius yang begitu tinggi membantu nasabah untuk melakukan transaksi perbankan dimana layanan Jenius dapat mempercepat waktu, memperlancar transaksi, dan membantu dalam pengelolaan dana sehingga dapat meningkatkan minat nasabah untuk menggunakan kembali layanan tersebut. Hasil penelitian ini mendukung hasil penelitian Chong et al., (2010), Fajar, (2016), dan Mentari et al., (2019) yang menyatakan bahwa persepsi manfaat berpengaruh signifikan terhadap minat menggunakan teknologi informasi.

Signifikansi persepsi kemudahan penggunaan $\left(X_{3}\right)$ 0,443 $>0,05$ dan nilai $t_{\text {hitung }}$ lebih kecil dari $\mathrm{t}_{\text {tabel }}(0,770<1,977)$, maka $\mathrm{H}_{0}$ diterima dan $\mathrm{H}_{3}$ ditolak. Dapat diartikan bahwa variabel persepsi kemudahan penggunaan tidak berpengaruh pada minat ulang menggunakan aplikasi mobile banking. Dikarenakan karakteristik responden pada penelitian ini didominasi oleh pelajar/mahasiswa (17-25 tahun), para nasabah Jenius tidak mengkawatirkan kemudahan penggunaan mobile banking karena saat ini para nasabah sudah mempunyai pengetahuan yang memadai. Para nasabah sudah paham akan teknologi, HP, dan komputer. Mereka menganggap bahwa mobile banking mudah digunakan, 
dikarenakan teknologi yang terus berkembang dari tahun ke tahun. Mudah atau tidaknya penggunaan mobile banking tidak mempengaruhi keputusan nasabah dalam menggunakan mobile banking. Berbeda dengan hasil penelitian yang didapatkan oleh Tjini \& Baridwan (2011), Pratiwi et al., (2018) dan Pratama \& Suputra (2019) yang menyatakan bahwa kemudahan penggunaan berpengaruh positif pada minat menggunakan transaksi elektronik. Hasil penelitian ini mendukung penelitian yang dilakukan oleh Ahmad \& Bambang Setiyo Pambudi, (2014) dan Cho \& Sagynov (2015) yang menyatakan bahwa persepsi kemudahan penggunaan tidak mempunyai pengaruh pada minat ulang nasabah menggunakan transaksi elektronik.

Signifikansi persepsi keamanan $\left(\mathrm{X}_{4}\right) 0,000<0,05$, dan nilai $\mathrm{t}_{\text {hitung }}$ lebih besar dari $\mathrm{t}_{\text {tabel }}(3,657>1,977)$, maka $\mathrm{H}_{0}$ ditolak dan $\mathrm{H}_{4}$ diterima. Dari hasil tersebut dapat diartikan bahwa variabel persepsi keamanan berpengaruh positif pada minat ulang menggunakan aplikasi mobile banking. Hal ini berarti bahwa semakin tinggi keamanan yang diberikan, maka semakin tinggi pula minat penggunaannya. Artinya, masyarakat percaya bahwa saat memakai mobile banking akan terjamin keamanannya, masyarakat tidak takut uang yang ada akan dibobol oleh pihakpihak yang tidak berkepentingan dan informasi pengguna yang bersifat rahasia juga akan terlindungi. Berbeda dengan hasil yang didapat oleh Dewan \& Chen (2005), Sari (2019) dan Sienatra (2020) yang menyatakan bahwa keamanan tidak berpengaruh pada minat menggunakan transaksi elektronik. Hasil penelitian ini konsisten dengan penelitian yang dilakukan oleh Ariani (2017) dan Virginia (2020) yang menyatakan terdapat pengaruh signifakan antara keamanan pada minat untuk menggunakan Line Pay.

\section{SIMPULAN}

Berdasarkan hasil analisis serta pembahasan yang telah diuraikan mengenai pengaruh dari masing-masing variabel bebas pada variabel terikat, terdapat empat hasil yang didapat. Persepsi kepercayaan berpengaruh positif pada minat ulang menggunakan aplikasi mobile banking Jenius. Persepsi kegunaan berpengaruh positif pada minat ulang menggunakan aplikasi mobile banking Jenius. Persepsi kemudahan penggunaan tidak berpengaruh pada minat ulang menggunakan aplikasi mobile banking Jenius. Persepsi Keamanan berpengaruh positif pada minat ulang mengunakan aplikasi mobile banking Jenius.

Adapun beberapa saran yang dapat dikemukakan, meskipun variabel kemudahan penggunaan tidak berpengaruh signifikan pada minat ulang menggunakan mobile banking, sekiranya pihak perusahaan tetap meningkatkan tampilan aplikasi, dan menambah fitur-fitur lain yang menambah nilai guna dari aplikasi mobile banking. Untuk peneliti selanjutnya, jika ingin meneliti topik yang sama, sebaiknya sampel yang digunakan lebih banyak supaya peluang kesalahan generalisasinya lebih kecil, selain itu diharapkan peneliti selanjutnya dapat menambah atau mengganti variabel supaya didapatkan hasil penelitian yang bervariasi. 


\section{REFERENSI}

Ahmad, \& Bambang Setiyo Pambudi. (2014). Pengaruh Persepsi Manfaat, Persepsi Kemudahan, Keamanan dan Ketersediaan Fitur Terhadap Minat Ulang Nasabah Bank dalam Menggunakan Internet Banking (Studi Pada Program Layanan Internet Banking BRI). Jurnal Studi Manajemen, 8(1).

Ariani, Z. M. (2017). Pengaruh Kualitas Layanan, Keamanan, Dan Risiko Terhadap Minat Menggunakan Line Pay. Prosiding Conference On Management and Behavioral Studies, 457-467.

Cho, Y. C., \& Sagynov, E. (2015). Exploring Factors That Affect Usefulness, Ease Of Use, Trust, And Purchase Intention In The Online Environment. International Journal of Management \& Information Systems (IJMIS), 19(1). https:// doi.org/10.19030/ijmis.v19i1.9086

Chuang, L., \& Kao. (2016). The Adoption of Fintech Service: TAM Perspective. International Journal of Management and Administrative Sceince, 3(7), 2225-7225.

Davis, F.D. (2009). Perceived Usefulness Perceivc-Ease of Use, and User Acceptance of Information Technology. Management Information Systems Quarterly, 319-342.

Davis, Fred D. (1989). Perceived Usefulness, Perceived Ease of Use, and User Acceptance of Information Technology. MIS Quarterly, 13(3). https://doi.org/10.2307/249008

Dewan, S. G., \& Chen, L. (2005). Mobile Payment Adoption in the US: A Crossindustry, Crossplatform Solution. Journal of Information Privacy and Security, 1(2). https:// doi.org/10.1080/15536548.2005.10855765

Fajar, A. H. (2016). Pengaruh Persepsi Risiko, Persepsi Kemudahan, Dan Persepsi Manfaat Terhadap Minat Pembelian Online Pada Website Lazada.co.id di Kota Malang. Jurnal Ilmiah Mahasiswa FEB Brawijaya, 3(2).

Hapsara, \& Noer. (2015). Pengaruh Kegunaan, Kemudahan, Resiko dan Kepercayaan Terhadap Penggunaan Mobile Banking (Studi Pada Nasabah Bank Bri Kantor Cabang Solo Kartasura). 10-17.

Jogiyanto. (2007). Sistem Informasi Keperilakuan.

Mentari, N. W., Setiawina, I. N. D., Budhi, I. M. K. S., \& Sudirman, I. W. (2019). Influence factor of consumers interest on using E-money. International Journal of Social Sciences and Humanities, 3(2). https://doi.org/10.29332/ijssh.v3n2.311

Mubiyantoro, A., \& Syaefullah. (2013). Pengaruh Persepsi Kegunaan, Persepsi Kemudahan Penggunaan, Persepsi Kesesuaian, dan Persepsi Risiko Terhadap Sikap Penggunaan Mobile Banking (Studi Kasus di Bank BRI Kota Malang). Jurnal Akuntansi Universitas Brawijaya Malang.

Much, F. A. (2018). Pengaruh Persepsi Kegunaan, Kepercayaan, dan Resiko Terhadap Minat Menggunakan Mobile Banking. IAIN Salatiga Repository.

Nasri, W., \& Zarai, M. (2014). Empirical Analysis Of Internet Banking Adoption In Tunisia. Asian Economic and Financial Review, 4(12), 1812-1825.

Pratama, A. B., \& Suputra, I. D. G. D. (2019). Pengaruh Persepsi Manfaat, Persepsi Kemudahan Penggunaan, dan Tingkat Kepercayaan Pada Minat Menggunakan Uang Elektronik. E-Jurnal Akuntansi. https:// doi.org/10.24843/EJA.2019.v27.i02.p04

Pratiwi, M. T., Indriani, F., \& Sugiarto, J. (2018). Analisis Pengaruh Technology 
Readiness Terhadap Minat Menggunakan T-Cash di Kota Semarang. JURNAL BISNIS STRATEGI, 26(1). https:// doi.org/10.14710/jbs.26.1.76-88

Romadloniyah, A. L., \& Prayitno, D. H. (2018). Pengaruh Persepsi Kemudahan Penggunaan, Persepsi Daya Guna, Persepsi Kepercayaan, dan Persepsi Manfaat Terhadap Minat Nasabah Dalam Menggunakan E-Money Pada Bank BRI Lamongan. Jurnal Penelitian Ekonomi Dan Akuntansi, 3(2), 699-711.

Sari, I. (2019). Pengaruh Kemudahan, Manfaat Penggunaan Teknologi, Fitur Layanan, dan Keamanan terhadap Minat Menggunakan E-Money dengan Sikap Penggunaan sebagai Variabel Intervening. IAIN Salatiga Repository.

Sienatra, K. (2020). Dampak persepsi manfaat dan persepsi risiko terhadap fintech continuance intention pada generasi milenial di Surabaya. Jurnal Nusantara Aplikasi Manajemen Bisnis, 5(1). https://doi.org/10.29407/nusamba.v5i1.14225

Sugiyono. (2013). Metode Penelitian Kuantitatfi Kualitatif dan REB. Alfabeta.

Suh, B., \& Han, I. (2003). The Impact of Customer Trust and Perception of Security Control on the Acceptance of Electronic Commerce. International Journal of Electronic Commerce, 7(3). https:// doi.org/10.1080/10864415.2003.11044270

Talatu O, G., Ibidapo O, A., \& Emmanuel O, A. (2014). The Impact of KnowledgeBased Trust (Kbt) on The Adoption and Acceptability of Cashless Economy in Nigeria. International Journal of Computer Science and Information Technology, 6(2). https:// doi.org/10.5121/ijcsit.2014.6213

Tenri Gobel. (2020, June). Dalam Sepekan, Akun Jenius BTPN Milik Dua Nasabah Ini Dibobol. Cyberthreat.Id.

Tjini, \& Baridwan. (2011). Pengaruh Kepercayaan, Persepsi Kegunaan, Persepsi Kemudahan, dan Persepsi Kenyamanan Terhadap Minat Penggunaan Sistem Internet Banking. Jurnal Ekonomi Dan Bisnis Universitas Brawijaya.

Utami, S. S., \& Kusumawati, B. (2017). Faktor - Faktor Yang Mempengaruhi Minat Penggunaan E-Money (Studi Pada Mahasiswa STIE Ahmad Dahlan Jakarta). Jurnal BALANCE STIE Ahmad Dahlan Jakarta, 14(2).

Virginia, E. (2020). Pengaruh Sikap, Kepercayaan, Persepsi Kemudahan, Persepsi Kegunaan, dan Keamanan Terhadap Minat Menggunakan Jasa Layanan Gojek. Jurnal Ilmiah Mahasiswa FEB Universitas Brawijaya, 8(2).

Widiyono, S. S. (2013). Metodologi Penelitian Sosial Untuk Penulisan Skripsi dan Tesis (Cetakan 1). In Media.

Wiratna, S. (2015). Metodologi Penelitian (cetakan 1). Pustaka Baru.

Yee-Loong Chong, A., Ooi, K., Lin, B., \& Tan, B. (2010). Online banking adoption: an empirical analysis. International Journal of Bank Marketing, 28(4). https:// doi.org/10.1108/02652321011054963 